J. Product. \& Dev., 12(1): 299 - 314 ( 2007)

\title{
A PILOT STUDY EXPLORING THE EFFECTS OF BEE HONEY AS A BIO- FERTILIZER ON THE MORPHOLOGICAL FEATURES AND CHEMICAL CONSTITUENTS OF Syngonium podophyllum PLANTS
}

\author{
Safia H. El-Hanafy \\ Ornamental Horticulture Department, Faculty of Agriculture, Cairo University, \\ Egypt.
}

\section{ABSTRACT}

Foliage ornamental plants are part and parcel of interiorscaping. Adequate fertilization is essential for their growth, and preservation of viability. Syngonium is a foliage perennial climbing indoor plant characterized by its variably-looking leaves according to its stage of development. Honey is a very complex bee product rich in essential, as well as trace elements, some of which is a component of plant sap, being sucked as nectar by the forager bee. The aim of this study is to explore the effect of spraying dilute preparations of bee honey, as a bio-fertilizer, on growth and chemical constituents of Syngonium podophyllum plants.

Terminal cuttings of Syngonium plant were planted in pots. The plants were divided into 8 groups. Two control groups of plants were used; the first received only water, while the second received Kristalon fertilizer at the rate of $1 \mathrm{~g} /$ plant every two weeks. The first three treatment groups were drenched with Kristalon fertilizer and sprayed with a diluted solution of honey at the concentrations of $1,1.5$ and $2 \%$ for T1, T2 and T3 respectively. The other three treatment groups were only sprayed with a diluted solution of honey at the same concentrations

The plants were left to grow under the condition of glass house for one month before starting treatment. The procedure of spraying and drenching was repeated for different groups every two weeks for a total of 7 months.

At the end of the experiment for every season, the following morphological data were recorded for all groups of plants: plant height, number of leaves per plant, leaf area for the $5^{\text {th }}$ leaf counted from below, fresh and dry weights of leaves per plant, stem diameter, fresh and dry weights of stems, root length, fresh and dry weights of roots.

The chemical analysis included the pigment content of chlorophyll $a$, chlorophyll $b$ and carotenoids in fresh leaves, and nitrogen, phosphorus, potassium and total carbohydrate percentages in dry leaves, the collected data were statistically analyzed.

The overall analyzed results indicate that, regular spraying of diluted honey for Syngonium podophyllum plants with, or even without Kristalon was associated with adequate growth of the above ground plant parts, with 
fluctuation of superiority between the use of honey alone or its use combined with the chemical fertilizer, Kristalon. Being a source of many essential plant nutrients and trace elements, honey can thus represent a highly nutritious fortifying bio-fertilizer that may be used alone or in conjunction with another fertilizer, with almost the same or slightly different results. However, the amount of available information is in need of further studies on different plants, using honey with /or alternative to different fertilizers to portrait a more clear picture of this bio-fertilizer in plant life.

Key words: Syngonium, honey, morphological features, chemical constituents

\section{INTRODUCTION}

Indoor foliage ornamental plants are widely used for interiorscaping. They are now taking an essential role as a component of interior design of public, as well as, private establishments. Consequently, these plants may represent an economic value for different countries. Adequate fertilization is essential for growth, and preservation of viability, with improvement of leaf features which represent the main element of decoration offered by these plants. Syngonium is a foliage perennial climbing indoor plant characterized by its variably-looking leaves according to its stage of development. Most of the known chemical fertilizers in use contain N., P., K. and trace elements which are essential nutrients for plant growth and development, and are commonly lacking in soil.

Honey is one of the secretory products of the pollinating, plant-sucking insect Apis mellifera (forager bee). During the formation of honey, bees depend on nectar which is secreted by glandular tissue of flowers. Thus, an important component of honey is a plant product. In addition, plant sap that is taken up by bees, and that exceeds their capacity, is secreted in small droplets to fall on the surface of leaves and solidify quickly forming honey dew, before being taken up again by bees. Some of the enzymes used in hives for ripening of honey are also of plant origin (Maurizio, 1975).

Honey is an aqueous dispersion of material covering a wide range of particle size including inorganic ions, monosaccharide's (mainly fructose and glucose), disaccharides (sucrose and other rare sugars as maltose and isomaltose), and polysaccharides (melezitose, raffinose, dextrin and others) (Shin and Ustunol, 2005). Proteins including albumins, globulins, peptones, nucleoproteins, amides, as well as amino acids are also present in honey (White, 1975). The main amino acids found in 31 Spanish honeys of five different single botanical origins, were proline, phenylalanine, tyrosine and lysine, followed by arginine, glutamic acid, histidine and valine (Hermosin et al, 2003).

However, its composition depends upon the components of nectar, and external factors as weather and bee keeper practices in extracting honey, as well as the period and condition of storage (Ouchemoukh et al, 2007). 
The $\mathrm{pH}$ of honey which averages 3.9 (3.2-4.5), is attributed to its acid content which includes organic acids like acetic, butyric, citric, gluconic, lactic, maleic, malic, oxalic, pyroglutamic, succinic and amino acids. Gluconic acid is present in considerable excess over all other acids, and is produced by the action of glucose oxidase in honey upon the dextrose in it. This acid is present in honey in equilibrium with its lactone. Acids corresponding to inorganic ions such as phosphate, chloride and sulphate may also be considered to be honey constituents (White, 1975).

Honey ash includes potassium, sodium, calcium, magnesium, chloride, phosphorus, sulphur and silica (Terrab et al, 2004). Honey also contains iron, copper and manganese. Small amounts of other elements have been found in some types of honey of different origins such as aluminum, iodine, boron, titanium, molybdenum, cobalt, zinc, lead, tin, antimony, chromium and nickel (Rashed and Soltan, 2004).

Honey also contains a battery of enzymes including glucose oxidase, catalase, invertase, acid phosphatase and diastase. Glucose oxidase acts on glucose in honey to form gluconic acid and hydrogen peroxide with its known antibacterial activity. Catalase enzyme acts on hydrogen peroxide in honey to release nascent oxygen. Diastase enzyme digests starch in honey (White, 1975).

Vitamin B (thiamine, riboflavin, pyridoxine, niacin and pantothenic acid) and vitamin $\mathrm{C}$ (ascorbic acid) represent minor constituents of honey. Other minor constituents include carotenoids, polyphenolic compounds, formaldehyde, acetaldehyde, acetone, isobuteraldehyde, diacetyl-hydroxymethyl-furaldehyde and others (White, 1975).

Sixty six volatile compounds were detected in Spanish citrus honeys (Vazquez et al, 2007)

Honey lipids include glycerides, sterols, phospholipids, fatty acids (palmetic, oleic, lauric, myristoleic, stearic and linoleic) and traces of bee wax (White, 1975). Antioxidant and scavengering activities of honey were confirmed by Kucuk et al (2007).

Flavonoids are major functional components of many herbal and insect preparations e.g., propolis (bee's glue) and honey, which have been used medically since ancient times. Flavonoids are plant pigments ubiquitous to green plant cells. The flavonoids are used by botanists for taxonomical classification. They regulate plant growth by inhibition of the exocytosis of the auxin indolyl acetic acid, as well as by induction of gene expression (Havsteen, 2002).

The aim of this study is to explore the effect of spraying dilute preparations of bee honey, as a biofertilizer, on growth and chemical constituents of Syngonium podophyllum plants.

\section{MATERIALS AND METHODS}

This experimental trial was performed throughout two successive seasons (2003/2004 and 2004/2005) at the Nursery of Ornamental Horticulture Department, Faculty of Agriculture, Cairo University, Egypt. 
Terminal cuttings of the perennial foliage plant, Syngonium podophyllum, taken from mother plants grown in the Nursery (each having 4 leaves, and was $15 \mathrm{~cm}$ high), were planted on Oct. $1^{\text {st }} 2003$ and 2004 (in the first and second seasons, respectively) in $20 \mathrm{~cm}$ diameter plastic pots filled with 1:1(by volume) mixture of fine sand and peat moss at a rate of one plant per pot. Chemical analysis of the growing medium was carried out by Soils and Waters Research Institute, Agriculture Research Center, as shown in Table A.

Table A: Chemical analysis of growing medium according to Soils and Waters Research Institute, Agriculture Research Center, Ministry of Agriculture

\begin{tabular}{|c|c|c|c|c|c|c|c|c|c|}
\hline \multirow{2}{*}{$\begin{array}{l}\text { Fine sand + } \\
\text { peat moss }\end{array}$} & \multicolumn{3}{|r|}{ Anions } & \multicolumn{4}{|c|}{ Cations (ppm) } & \multirow[t]{2}{*}{$\mathrm{pH}$} & \multirow{2}{*}{$\begin{array}{c}\text { EC } \\
\text { Mmhos } / \mathrm{cm}\end{array}$} \\
\hline & $\mathrm{HCO}_{3}^{-}$ & $\mathrm{Cl}^{-}$ & $\mathrm{SO}_{4}^{--}$ & $\mathrm{Ca}^{++}$ & $\mathbf{M g}^{++}$ & $\mathrm{Na}^{+}$ & $\mathbf{K}^{+}$ & & \\
\hline & 5.2 & 6.4 & 9.5 & 6 & 3.4 & 9.6 & 2.0 & 7.2 & 1.3 \\
\hline & $\mathrm{N}$ & $P$ & K & $\mathrm{Fe}$ & $\mathrm{Zn}$ & $\mathrm{Mn}$ & & & \\
\hline & 52 & 14.29 & 60.45 & 5.86 & 6.2 & 14.78 & & & \\
\hline
\end{tabular}

The plants were divided into 8 groups (shown in Table B), each consisting of 18 plants. Two control groups of plants were used, the first received only water, while the second received Kristalon fertilizer containing N: P: K: Mg (19; 19:19:2), at the rate of $1 \mathrm{~g} /$ plant every two weeks. The first three treatment groups were drenched with Kristalon fertilizer and sprayed with a diluted solution of honey at the concentrations of $1,1.5$ or $2 \%$ for T1, T2 and T3 respectively. The other three treatment groups were only sprayed with a diluted solution of honey at the concentrations of $1,1.5$ or $2 \%$ for T4, T5 and T6, respectively.

Table B:

\section{Procedure (every 2 weeks)}

\begin{tabular}{lll}
\hline Groups & Drenching & Spraying \\
\hline C1 & Water & Water \\
C2 & Kristalon 1g /plant & Water \\
T1 & Kristalon 1g /plant & Honey 1\% \\
T2 & Kristalon 1g /plant & Honey 1.5\% \\
T3 & Kristalon 1g /plant & Honey 2\% \\
T4 & Water & Honey 1\% \\
T5 & Water & Honey 1.5\% \\
T6 & Water & Honey 2\% \\
\hline
\end{tabular}

$(\mathrm{C})=$ Control. $\quad(\mathrm{T})=$ Treatment groups

The honey used in spraying was an Egyptian product, licensed by the Egyptian ministry of health under the number 3682-2005, and attested by the American 
Systems Registrar, a provider of ISO 9000, accredited by the ANSI-ASQ National Accreditation Board.

The plants were left to grow under the condition of glass house for one month before starting treatment. The procedure of spraying and drenching was repeated for different groups (shown in Table b) every two weeks till the first of July (a total of 7 months from the beginning of treatment for every season). Regular agricultural practices such as irrigation, weeding .....etc were carried out whenever necessary.

At the end of the experiment for every season, the following morphological data were recorded for all groups of plants: plant height $(\mathrm{cm})$, number of leaves per plant, leaf area $(\mathrm{cm} 2)$ for the $5^{\text {th }}$ leaf counted from below, fresh and dry weights of leaves per plant (g.), stem diameter $(\mathrm{cm})$, fresh and dry weights of stems $(\mathrm{g}$.), root length $(\mathrm{cm})$, fresh and dry weights of roots $(\mathrm{g})$.

The chemical analysis included the pigment content of chlorophyll a, chlorophyll $\mathrm{b}$ and carotenoids (mg/g.) in fresh leaves (a method of estimation according to Saric et al, 1976), and nitrogen, phosphorus, potassium and total carbohydrate percentages in dry leaves. Nitrogen percentage was estimated by Nesslar method according to the procedure of A.O.A.C. (1960). Phosphorus percentage was determined according to Troug and Meyer (1939). Potassium percentage was determined by using Flame Photometer 410 (Dewis and Freitas, 1970). Carbohydrate percentage was determined according to Dubois et al (1956).

The design for this experiment was Complete Randomized Design (CRD) with three replicates. Data were statistically analyzed with the Analysis of Variance (ANOVA) according to Snedecor and Cochran (1980) using Mstatc program. When significant differences $(\mathrm{P}<0.05)$ were detected, the least significant difference (LSD) test was used to separate the mean values according to Steel and Torrie (1981).

\section{RESULTS AND DISCUSSION}

\section{Morphological changes (Table 1\&2)}

\subsection{Plant height $(\mathrm{cm})$}

In comparison to the first control (C1), data in Table 1 show clear increment in plant height with all treatments in both seasons, with the increase being significant in most of the treatments. In comparison to the second control (C2), five of the treatments had significantly higher results in both seasons. In comparing the first triad of treatments ( 3 treatments consisting of honey at 3 concentrations + Kristalon) with the second triad (the other 3 treatments consisting of honey alone at 3 concentrations), Honey alone gave higher results in both seasons $(75.72$ versus $70.73 \mathrm{~cm}$ and 95.17 versus $79.59 \mathrm{~cm}$ for the first and second seasons respectively). Honey alone at $1 \%$ (T4) gave the highest results in both seasons (85.22 and $99.11 \mathrm{~cm}$ with T4 compared to 63.37 and $75.25 \mathrm{~cm}$ with Kristalon alone in C2 in the first and second seasons, respectively).

\subsection{Leaf parameter (Table 1) 1.2.1. Number of leaves /plants}


In comparison to $\mathrm{C} 1$, data show increment in plant height with all treatments in both seasons, with the increase being significant in most of the treatments. In comparison to $\mathrm{C} 2$, no significant differences were recorded with any of the treatments in the first season, while three treatments (T1, T5, T6) gave significantly higher results in the second season. On comparing the two triads of treatment (the triad of honey with Kristalon in comparison to the triad of honey alone), the mean value was significantly higher with the first triad in the first season (12.30 versus 11.28 leaves /plant), and with the second triad in the second season (14.90 versus 13.87 leaves /plant). The highest result was recorded with $\mathrm{T} 1$ (honey at $1 \%+$ Kristalon) in both seasons.

\subsubsection{Leaf area $\left(\mathrm{cm}^{2}\right)$}

In comparison to $\mathrm{C} 1$, data show increment in leaf area with all treatments in both seasons; with the increase being significant in most of the treatments (it was insignificant only with $\mathrm{T} 3$ in the second season). In comparison to $\mathrm{C} 2$, leaf area was higher with all the honey alone-treatments in both seasons, with the increments being significant in the first season. T1(honey $1 \%$ with Kristalon) gave significantly higher results in both seasons compared to $\mathrm{C} 2$ (Kristalon alone). On comparing the two triads of treatment, honey alone was associated with higher results in both seasons, with significance in the first (169.31 versus $139.46 \mathrm{~cm}^{2}$ and 118.74 versus $118.23 \mathrm{~cm}^{2}$ for the first and second seasons respectively). The best results were recorded with honey $1 \%$ in the first season, and honey $1 \%$ with Kristalon in the second.

\subsubsection{Fresh weight of leaves (g)}

In comparison to $\mathrm{C} 1$, all treatments in both seasons gave significantly higher results except for only one insignificant increment with T3 in the second season. In comparison to $\mathrm{C} 2$, no significant differences were noted with most of the treatments in both seasons. On comparing the two triads of treatment (the triad of honey with Kristalon in comparison to the triad of honey alone), the mean value was significantly higher with the first triad in the first season (36.31 versus $29.88 \mathrm{~g}$ ), and with the second triad (with insignificance) in the second season. The highest result was recorded with $\mathrm{T} 1$ (honey at $1 \%+$ Kristalon) in both seasons.

\subsubsection{Dry weight of leaves $(\mathrm{g})$}

In comparison to $\mathrm{C} 1$, all treatments in both seasons gave higher results. In comparison to $\mathrm{C} 2$, irregular results were recorded with no clear trend in either season.

On comparing the two triads of treatment (the triad of honey with Kristalon in comparison to the triad of honey alone), the mean value was significantly higher with the first triad in the first season (8.80 versus $6.95 \mathrm{~g}$ ), and with the second triad (with insignificance) in the second season. The highest result was recorded with T1 (honey at $1 \%+$ Kristalon) in the first season, and with $\mathrm{T} 5$ (honey alone at $1.5 \%$ ) in the second. 


\begin{tabular}{|c|c|c|c|c|c|c|c|c|c|c|c|c|c|c|c|c|}
\hline 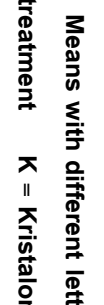 & 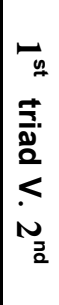 & 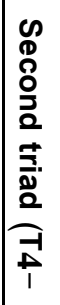 & 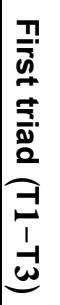 & $\begin{array}{l}5 \\
0 \\
2 \\
\tilde{0} \\
\dot{0} \\
u\end{array}$ & 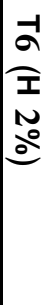 & 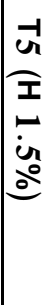 & 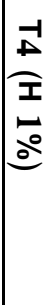 & 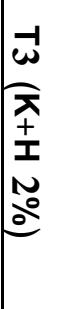 & 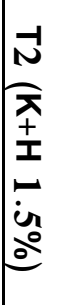 & 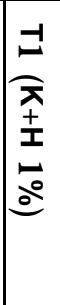 & 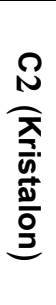 & 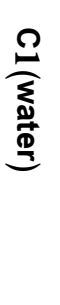 & & & 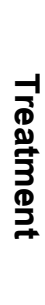 & $\frac{\frac{-1}{\frac{\sigma}{0}}}{2}$ \\
\hline 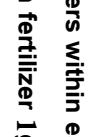 & $\mathbf{z}_{\text {is }}$ & $\begin{array}{l}\text { Ŭ } \\
\dot{N}\end{array}$ & 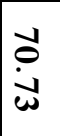 & $\begin{array}{l}\hat{\theta} \\
\dot{A}\end{array}$ & $\begin{array}{l}y \\
\dot{y} \\
\vdots \\
0\end{array}$ & $\begin{array}{l}J \\
\dot{\omega} \\
\\
0\end{array}$ & 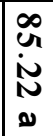 & 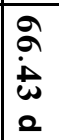 & $\begin{array}{l}9 \\
\dot{p} \\
\dot{u} \\
u\end{array}$ & $\begin{array}{l}\infty \\
\dot{N} \\
\sigma \\
\sigma\end{array}$ & $\begin{array}{l}\underset{\omega}{\omega} \\
\dot{\omega} \\
\dot{0}\end{array}$ & $\underset{n}{0}$ & $\stackrel{g}{\sim}$ & & $\begin{array}{l}\frac{\bar{v}}{2} \\
\frac{2}{2} \\
\bar{\sigma}\end{array}$ & 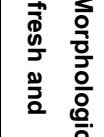 \\
\hline 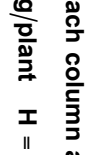 & $a s$ & 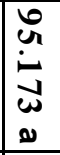 & $\begin{array}{l}\text { J } \\
\dot{\omega} \\
\dot{b} \\
\sigma \\
\sigma\end{array}$ & $\ddot{N}$ & 选 & $\begin{array}{l}0 \\
\omega \\
\infty \\
0 \\
0\end{array}$ & ๑ & $\begin{array}{l}\alpha \\
0 \\
\dot{9} \\
0\end{array}$ & $\mid \begin{array}{l}\infty \\
+ \\
\infty \\
\infty \\
0 \\
0\end{array}$ & $\mid \begin{array}{l}\infty \\
0 \\
i \\
i \\
u \\
n \\
n\end{array}$ & 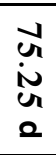 & 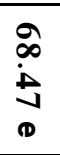 & Na & & $\begin{array}{l}\frac{\frac{0}{0}}{2} \\
\frac{+}{3} \\
\frac{0}{3}\end{array}$ & 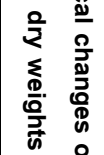 \\
\hline 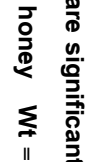 & 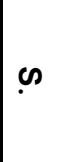 & $\begin{array}{l}= \\
\dot{N} \\
\infty \\
\omega \\
\sigma\end{array}$ & $\begin{array}{l}\tilde{N} \\
\dot{\omega} \\
\stackrel{\omega}{\omega} \\
\dot{\omega} \\
\infty\end{array}$ & $\begin{array}{l}\dot{0} \\
\dot{\infty} \\
\dot{\infty} \\
\infty\end{array}$ & 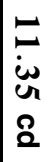 & 官 & 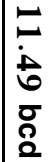 & $\begin{array}{l}\bar{n} \\
\dot{\omega} \\
a \\
\tilde{\omega} \\
\tilde{\omega}\end{array}$ & 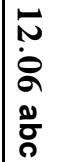 & 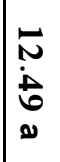 & $\underset{\dot{\infty}}{\vec{\Delta}}$ & $\begin{array}{l}0 \\
\dot{\infty} \\
0 \\
0\end{array}$ & $\stackrel{n}{ }$ & & $\begin{array}{l}z \\
\mathbf{z} \\
3 \\
\mathfrak{0} \\
\mathbb{1}\end{array}$ & 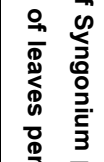 \\
\hline 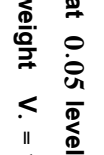 & \begin{tabular}{|r}
$z$ \\
is
\end{tabular} & $\stackrel{F}{\dot{8}}$ & $\begin{array}{l}\omega \\
\dot{\infty} \\
\dot{v}\end{array}$ & $\mid \overrightarrow{\dot{\infty}}$ & $\begin{array}{l}\vec{u} \\
\dot{\tilde{\omega}} \\
\omega \\
\nu\end{array}$ & $\begin{array}{l}\vec{u} \\
\dot{u} \\
\dot{v} \\
\vec{y}\end{array}$ & $\overrightarrow{\vec{\omega}}$ & $\stackrel{\vec{N}}{\stackrel{N}{N}}$ & $\mid \begin{array}{l}\omega \\
\infty \\
\infty \\
\infty\end{array}$ & $\begin{array}{l}\vec{e} \\
\dot{a} \\
\dot{a}\end{array}$ & $\begin{array}{l}\bar{\omega} \\
\dot{\dot{\omega}}\end{array}$ & $\begin{array}{l}\vec{\varphi} \\
\dot{y} \\
\varrho\end{array}$ & Na & & & 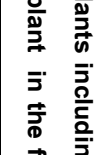 \\
\hline 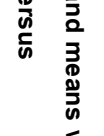 & 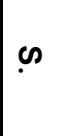 & $\begin{array}{l}\vec{\beta} \\
\dot{\omega} \\
\omega\end{array}$ & $\mid \begin{array}{l}w_{0} \\
\dot{b} \\
\dot{a}\end{array}$ & $\mid \begin{array}{l}0 \\
\infty \\
\infty\end{array}$ & $\begin{array}{l}\overrightarrow{9} \\
\dot{9} \\
8\end{array}$ & $\begin{array}{l}\vec{\partial} \\
\hat{\alpha} \\
\dot{\omega} \\
\dot{\omega}\end{array}$ & 式 & $\begin{array}{l}\bar{N} \\
\dot{n} \\
\dot{N}\end{array}$ & 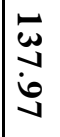 & $\begin{array}{l}\bar{u} \\
u \\
\dot{\omega} \\
\infty \\
\infty\end{array}$ & $\begin{array}{l}\overrightarrow{\mathbb{N}} \\
\stackrel{\overrightarrow{\mathrm{B}}}{\mathrm{C}}\end{array}$ & $\begin{array}{l}\overrightarrow{0} \\
\stackrel{0}{0} \\
\dot{\infty}\end{array}$ & - & & $\begin{array}{l}\frac{7}{9} \\
\frac{7}{8}\end{array}$ & 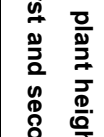 \\
\hline $\bar{\Phi}$ & $\mathbf{z}_{\text {is }}$ & $\varpi$ & $\varpi$ & $\begin{array}{l}\infty \\
\dot{\hat{u}}\end{array}$ & Ĕ & $\underset{\infty}{\vec{\infty}}$ & $\mathbb{N}$ & ڤ̊ & 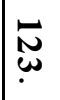 & 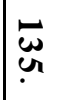 & $\vec{\rightleftarrows}$ & 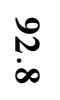 & $N_{z}$ & & 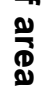 & 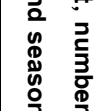 \\
\hline $\begin{array}{l}\frac{0}{0} \\
\stackrel{0}{\sigma}\end{array}$ & 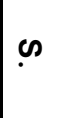 & $\begin{array}{l}N \\
\infty \\
\infty \\
\infty\end{array}$ & $\mid \begin{array}{l}\omega \\
\mathscr{\omega} \\
\dot{\omega}\end{array}$ & $\stackrel{+}{\underset{N}{N}}$ & $\begin{array}{l}\text { No } \\
\dot{\omega}\end{array}$ & $\begin{array}{l}\text { No } \\
\dot{\tilde{N}} \\
\sigma\end{array}$ & 岂 & $\begin{array}{l}\mathscr{e} \\
\stackrel{\varphi}{+} \\
\dot{\omega}\end{array}$ & $\begin{array}{l}\tilde{\omega} \\
\omega \\
\dot{\omega} \\
\omega\end{array}$ & $\begin{array}{l}+ \\
+\dot{+} \\
\dot{i=1}\end{array}$ & $\begin{array}{l}\omega \\
\stackrel{\omega}{\sigma} \\
\dot{\sigma}\end{array}$ & $\begin{array}{l}\hat{N} \\
\hat{\sigma}\end{array}$ & $T_{\underline{n}}$ & 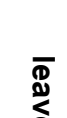 & $\frac{\pi}{\vec{D}}$ & 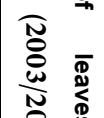 \\
\hline 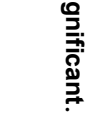 & $\boldsymbol{z}_{\text {is }}$ & 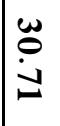 & $\begin{array}{l}N \\
\text { No } \\
\text { No }\end{array}$ & $\underset{\dot{\omega}}{\dot{\omega}}$ & 苾 & & $\stackrel{\mathscr{N}}{\stackrel{N}{=}}$ & $\begin{array}{l}\text { No } \\
\dot{a} \\
\dot{A}\end{array}$ & $\begin{array}{l}\tilde{n} \\
\ddot{\alpha} \\
\dot{\infty}\end{array}$ & $\begin{array}{l}\omega \\
\vec{v} \\
\dot{t} \\
\omega\end{array}$ & $\begin{array}{l}\stackrel{N}{a} \\
\dot{i}\end{array}$ & $\begin{array}{l}\infty \\
\dot{N} \\
\dot{\sigma}\end{array}$ & $\stackrel{N}{a}$ & $\widehat{e}$ & $\stackrel{\circ}{\Omega}$ & 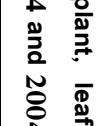 \\
\hline 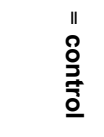 & ss & $\begin{array}{l}\hat{j} \\
\dot{\delta} \\
u \\
\sigma\end{array}$ & $\begin{array}{l}\infty \\
\dot{\infty} \\
0 \\
\infty\end{array}$ & $\overrightarrow{\dot{\vec{D}}}$ & $\begin{array}{l}0 \\
\dot{0} \\
0 \\
0\end{array}$ & $\stackrel{\grave{\sigma}}{\partial}$ & $\overrightarrow{\tilde{N}}$ & $\begin{array}{l}\vec{u} \\
\dot{i} \\
\dot{y}\end{array}$ & $\begin{array}{l}1 \\
\dot{0} \\
0\end{array}$ & $\overrightarrow{\dot{\vec{u}}}$ & $\underset{\sigma}{\stackrel{i}{N}}$ & $\begin{array}{l}u \\
\ddot{a} \\
a\end{array}$ & $\cong$ & 胥 & $g$ & \\
\hline -1 & $\mathbf{z}_{\text {is }}$ & $\mid \begin{array}{l}\lambda \\
\infty \\
\infty\end{array}$ & $\underset{\dot{\omega}}{\infty}$ & $\overrightarrow{\dot{\omega}_{\omega}}$ & $\hat{a}$ & $\dot{0}$ & $\dot{\vec{\omega}}$ & $\ddot{y}$ & $\dot{\overrightarrow{\hat{N}}}$ & ĭ & & $\stackrel{\overrightarrow{\dot{\omega}}}{\dot{\omega}}$ & $\Xi$ & $\widehat{\theta}$ & $\stackrel{\circ}{\rightarrow}$ & \\
\hline
\end{tabular}




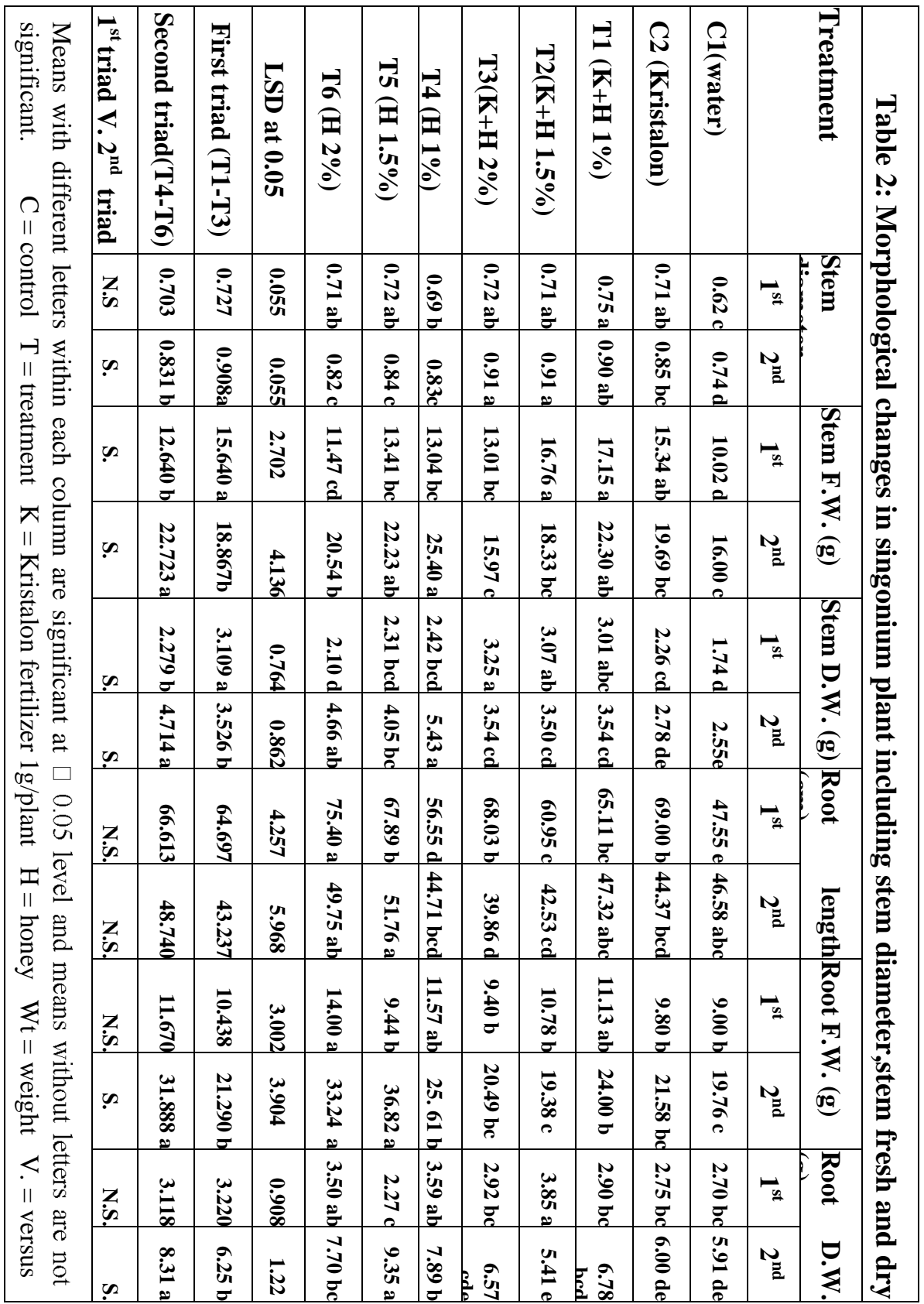




\subsection{Stem parameters (Table 2)}

\subsubsection{Stem diameter $(\mathrm{cm})$}

In comparison to $\mathrm{C} 1$, all treatments were associated with increments in both experimental seasons. In comparison to $\mathrm{C} 2$, insignificance was the main feature among results in the first season, while the combination of honey with Kristalon gave almost significantly higher results in the second. On comparing the two triads of treatment, the mean value of the first triad was insignificantly higher in the first season, and significantly higher $(0.908$ versus $0.831 \mathrm{~cm})$ in the second. The highest result was recorded with $\mathrm{T} 1$ (honey at $1 \%+$ Kristalon) in the first season, and with $\mathrm{T} 2$ and $\mathrm{T} 3$ in the second.

\subsubsection{Fresh weight of stem (g)}

In comparison to $\mathrm{C} 1$, all treatments gave higher results in both seasons. In comparison to $\mathrm{C} 2$, irregular results were recorded in both seasons with no clear trend. On comparing the two triads of treatment (the triad of honey with Kristalon in comparison to the triad of honey alone), the mean value was significantly higher with the first triad in the first season, and with the second triad $(22.72$ versus $18.87 \mathrm{~g})$ in the second season. The highest result was recorded with T1 (honey at 1\% + Kristalon) in the first season, and with T4 (Honey alone at 1\%) in the second.

\subsubsection{Dry weight of stem (g)}

All treatments were associated with higher results in comparison to water (C1), as well as to Kristalon (C2) in both seasons. . On comparing the two triads of treatment (the triad of honey with Kristalon in comparison to the triad of honey alone), the mean value was significantly higher with the first triad in the first season, and with the second triad (4.71 versus $3.53 \mathrm{~g}$ ) in the second season. The highest result was recorded with T3 (honey at $2 \%$ + Kristalon) in the first season, and with T6 (Honey alone at 2\%) in the second.

Generally speaking, shoot growth was enhanced in the presence of honey treatments, whether alone or mixed with Kristalon fertilizer, with either situation swinging alternatively towards the top. This may infer that honey might be used alone to guarantee almost the same degree of shoot enhancement. This, however, should be confirmed by further experiments on different plants, as there are no available studies to be compared to the results of this work.

In this study, the rate of application of diluted honey was every two weeks. Increasing the frequency of application may possibly give better results. Khattab (1997) noticed that increasing the frequency of spraying of a nutrient solution containing $\mathrm{Mg}, \mathrm{Mn}, \mathrm{Cu}, \mathrm{Zn}, \mathrm{B}$, Mo and Co onto Hibiscus sabdariffa increased plant growth.

Diluted honey may be tried in future studies as a hydroponic nutrient solution. Kang and Iersel (2004) studied the effect of nutrient concentration of the fertilizer Hoagland nutrient solution on growth of salvia and found that shoot growth increased with increasing nutrient solution concentration. 


\subsection{Root parameters (Table 2)}

\subsubsection{Root length $(\mathrm{cm})$}

Significantly higher results were recorded with all treatments in the first season in comparison to water $(\mathrm{C} 1)$, while irregular results were recorded in the second. In comparison to $\mathrm{C} 2$, no clear trend was noted in either season. The mean of the second triad (honey alone) was insignificantly higher in both seasons in comparison to the first triad of treatments (honey with Kristalon). The longest root value was recorded with $\mathrm{T} 6$ in the first and $\mathrm{T} 5$ in the second season.

\subsubsection{Fresh weight of roots (g)}

In comparison to $\mathrm{C} 1$, no remarkable differences were recorded with most treatments in both seasons. In comparison to $\mathrm{C} 2$, honey-alone treatments were generally associated with higher results, while the honey-Kristalon combinations had no remarkable associated results. On comparing the two triads of treatments, the honey-alone treatments were associated with higher results in both seasons, with the increments being significant in the second. The heaviest fresh weight of roots was associated with T6 in the first season and T5 in the second.

\subsubsection{Dry weight of roots (g)}

In comparison to $\mathrm{C} 1$, half of the treatments (T2, $\mathrm{T} 4$, and $\mathrm{T} 6$ ) had significantly higher results, while the other treatments showed no remarkable differences in the first season. The honey-alone treatments had significantly higher results in the second season compared to $\mathrm{C} 1$. In comparison to $\mathrm{C} 2$, only $\mathrm{T} 2$ treatment had a significantly higher result in the first season, while all the honey-alone treatments had significantly higher results in the second season. Comparison of the two triads revealed a higher first triad in the first season and a significantly higher second triad (the honey-alone treatments) in the second season. The heaviest roots were recorded with $\mathrm{T} 2$ in the first season and T5 in the second.

\section{Chemical constituents in leaves (Table 3)}

\subsection{Pigments $\{\mathrm{mg} / \mathrm{g}$ in fresh weight (F.W.) of leaves $\}$}

\subsubsection{Chlorophyll ( $A)$}

In comparison to $\mathrm{C} 1$, almost all treatments had higher results in both seasons. In comparison to $\mathrm{C} 2$, the results of all treatments were lower in the first season, while they demonstrated significant increments with T5 and T6 in the second season. The honey-Kristalon triad of treatments was insignificantly higher than the honey-alone triad in the first season, while the honey-alone triad was significantly higher $(0.88$ versus $0.78 \mathrm{mg} / \mathrm{g}$ ) in the second season. The highest record of chlorophyll a was that with Kristalon alone in the first season, while it was with honey $2 \%$ alone in the second season.

\subsubsection{Chlorophyll (B)}

Most of the treatments gave higher results in comparison with $\mathrm{C} 1$ and lower results in comparison with $\mathrm{C} 2$ in both seasons. The first triad of treatments had higher 
results than the second triad in both seasons, with insignificance in the second season. The highest records of chlorophyll $b$ content were those with Kristalon alone in the first season, and equally with Kristalon alone and honey $2 \%+$ Kristalon in the second season.

\subsubsection{Carotenoids}

Almost all treatments were associated with decreased results in comparison to both controls in both seasons. In addition, no significant differences were recorded between the results of the honey-Kristalon treatments and the honey-alone treatments in both seasons. The highest content of carotenoids was recorded with Kristalon alone in the first season, and with water alone or with honey $2 \%+$ Kristalon in the second season.

Utriainen and Holopainen (2001) studied the influence of nitrogen and phosphorus availability on Norway spruce seedlings and concluded that chlorophyll a $\& b$ as well as carotenoids increased significantly in response to the nitrogen and phosphorus treatment. On the other hand, Doncheva et al (2001), on pepper, detected drop in pigment content with nitrogen deficiency, with the conclusion that, nitrogen plays an important role in the synthesis of chloroplast.

Table 3. Chemical constituents: pigment content $(\mathrm{mg} / \mathrm{g})$ in fresh leaves of Syngonium plant in response to honey in the first and second seasons

\begin{tabular}{|c|c|c|c|c|c|c|}
\hline \multirow[t]{2}{*}{ Treatment } & \multicolumn{2}{|c|}{ Chlorophyll a } & \multicolumn{2}{|c|}{ Chlorophyll b } & \multicolumn{2}{|c|}{ Carotenoids } \\
\hline & $1^{\text {st }}$ & $2^{\text {nd }}$ & $1^{\text {st }}$ & $2^{\text {nd }}$ & $1^{\text {st }}$ & $2^{\text {nd }}$ \\
\hline C1:water & $0.86 \mathrm{~d}$ & $0.76 d$ & $0.30 \mathrm{~cd}$ & $0.24 \mathrm{bc}$ & $0.41 a b$ & 0.31 a \\
\hline C2:Kristalon & $1.13 \mathrm{a}$ & $0.81 \mathrm{c}$ & 0.38 a & $0.28 \mathrm{a}$ & $0.44 \mathrm{a}$ & $0.30 a$ \\
\hline $\mathrm{T} 1: \mathrm{K}+\mathrm{H} 1 \%$ & $0.95 \mathrm{c}$ & $0.76 d$ & 0.37 a & $0.26 a b$ & $0.38 \mathrm{~b}$ & $0.29 a$ \\
\hline $\mathrm{T} 2: \mathrm{K}+\mathrm{H} 1.5 \%$ & $0.89 \mathrm{~d}$ & $0.79 \mathrm{~cd}$ & 0.32 bc & $0.28 a$ & $0.25 \mathrm{~d}$ & $0.24 \mathrm{~b}$ \\
\hline $\mathrm{T} 3: \mathrm{K}+\mathrm{H} 2 \%$ & $1.06 \mathrm{~b}$ & $0.78 \mathrm{~cd}$ & $0.35 a b$ & $0.27 a b$ & $0.40 \mathrm{~b}$ & 0.31 a \\
\hline T4: H 1\% & $0.96 \mathrm{c}$ & $0.79 \mathrm{~cd}$ & 0.32 bc & $0.26 a b$ & $0.34 \mathrm{c}$ & $0.30 a$ \\
\hline T5: H $1.5 \%$ & $0.89 \mathrm{~d}$ & $0.89 \mathrm{~b}$ & $0.30 \mathrm{~cd}$ & 0.22 c & $0.27 \mathrm{~d}$ & $0.25 \mathrm{~b}$ \\
\hline T6: H 2\% & $0.93 \mathrm{c}$ & $0.95 a$ & 0.32 bc & $0.26 a b$ & $0.33 \mathrm{c}$ & $0.29 a$ \\
\hline LSD at 0.05 & 0.031 & 0.034 & 0.034 & 0.034 & 0.036 & 0.034 \\
\hline $1^{\text {st }}$ triad:T1-T3 & 0.97 & $0.78 \mathrm{~b}$ & $0.35 \mathrm{a}$ & 0.27 & 0.34 & 0.28 \\
\hline $2^{\text {nd }}$ triad:T4-T6 & 0.93 & $0.88 a$ & $0.31 \mathrm{~b}$ & 0.25 & 0.31 & 0.28 \\
\hline $1^{\text {st }}$ triad V. $2^{\text {nd }}$ triad & N.S. & s. & s. & N.S. & N.S. & N.S. \\
\hline
\end{tabular}

Means with different letters within each column are significant at $\mathrm{P}<0.05$ level and means without letters are not significant $\mathrm{LSD}=$ least significant difference. $\quad \mathrm{C}=\mathrm{Control}$ $\mathrm{T}=$ Treatment $\mathrm{K}=$ Kristalon $\quad \mathrm{H}=$ Honey $\quad \mathrm{V} .=$ Versus. 


\subsection{Nitrogen percentage (Table 4)}

In comparison to $\mathrm{C} 1$, no characteristic differences were recorded, as both seasons were associated with higher, lower or almost equal results. In comparison to $\mathrm{C} 2$, higher results were recorded with all treatments in the first season, while the second was associated with irregular differences. Comparison of the two triads of treatments revealed almost equal results in the first season, and significantly higher first triad results $(1.31$ versus $1.21 \%)$ in the second season. The highest nitrogen content was recorded with honey $1.5 \%+$ Kristalon in both seasons.

Table 4. Chemical constituents: N., P., K. and carbohydrate percentages in dry leaves of Syngonium plant in response to honey in the first and second seasons

\begin{tabular}{|c|c|c|c|c|c|c|c|c|}
\hline \multirow[t]{2}{*}{ Treatments } & \multicolumn{2}{|c|}{ Nitrogen } & \multicolumn{2}{|c|}{ Phosphorus } & \multicolumn{2}{|c|}{ Potassium } & \multicolumn{2}{|c|}{ Carbohydrate } \\
\hline & $1^{\text {st }}$ & $2^{\text {nd }}$ & $1^{\text {st }}$ & $2^{\text {nd }}$ & $1^{\text {st }}$ & $2^{n d}$ & $1^{\text {st }}$ & $2^{\text {nd }}$ \\
\hline C1:Water & $1.11 \mathrm{bc}$ & $1.30 \mathrm{~b}$ & $0.43 \mathrm{c}$ & $0.37 \mathrm{bc}$ & $1.56 \mathrm{~b}$ & $1.66 \mathrm{a}$ & $30.26 \mathrm{c}$ & 35.66 \\
\hline $\begin{array}{l}\text { C2:Kristal } \\
\text { on }\end{array}$ & $1.06 \mathrm{c}$ & $1.27 \mathrm{bc}$ & $0.51 \mathrm{ab}$ & $0.38 \mathrm{~b}$ & $1.42 \mathrm{~d}$ & $1.60 \mathrm{a}$ & $37.81 a b$ & 32.66 \\
\hline $\begin{array}{l}\mathrm{T} 1: \mathrm{K}+ \\
\mathrm{H} 1 \%\end{array}$ & $1.09 \mathrm{bc}$ & $1.20 \mathrm{~cd}$ & $0.45 \mathrm{bc}$ & $0.31 \mathrm{~cd}$ & $1.36 \mathrm{e}$ & $1.62 \mathrm{a}$ & $39.09 a b$ & 34.67 \\
\hline $\begin{array}{l}\mathrm{T} 2: \mathrm{K}+ \\
\mathrm{H} 1.5 \%\end{array}$ & $1.46 \mathrm{a}$ & $1.39 \mathrm{a}$ & $0.52 \mathrm{ab}$ & $0.16 \mathrm{e}$ & $1.58 \mathrm{~b}$ & $1.15 \mathrm{~d}$ & $37.63 \mathrm{~d}$ & 31.97 \\
\hline $\begin{array}{l}\mathrm{T} 3: \mathrm{K}+ \\
\mathrm{H} 2 \%\end{array}$ & $1.07 \mathrm{bc}$ & $1.33 \mathrm{ab}$ & $0.38 \mathrm{c}$ & 0.52 a & $1.76 \mathrm{a}$ & $1.44 \mathrm{~b}$ & $38.56 \mathrm{ab}$ & 33.24 \\
\hline T4: H 1\% & $1.41 \mathrm{a}$ & $1.14 \mathrm{~d}$ & 0.58 a & $0.34 \mathrm{bc}$ & $1.22 \mathrm{f}$ & $1.38 \mathrm{~b}$ & $28.39 \mathrm{c}$ & 33.00 \\
\hline ;:H 1.5\% & $1.14 \mathrm{~b}$ & $1.20 \mathrm{~cd}$ & $0.25 \mathrm{~d}$ & $0.27 \mathrm{~d}$ & $1.13 \mathrm{~g}$ & $1.38 \mathrm{~b}$ & 39.95 a & 36.37 \\
\hline T6: H 2\% & $1.09 \mathrm{bc}$ & $1.28 \mathrm{~b}$ & $0.52 \mathrm{ab}$ & $0.36 \mathrm{bc}$ & $1.48 \mathrm{c}$ & $1.26 \mathrm{c}$ & $39.59 a b$ & 36.18 \\
\hline$D$ at 0.05 & 0.08 & 0.08 & 0.08 & 0.05 & 0.05 & 0.09 & 2.14 & N.S \\
\hline $\begin{array}{l}1^{\text {st }} \text { triad: } \\
\mathrm{T} 1-\mathrm{T} 3\end{array}$ & 1.21 & $1.31 \mathrm{a}$ & 0.45 & 0.33 & $1.57 \mathrm{a}$ & 1.40 & 38.43 & 33.29 \\
\hline $\begin{array}{l}2^{\text {nd }} \text { triad: } \\
\text { T4-T6 }\end{array}$ & 1.22 & $1.21 \mathrm{~b}$ & 0.45 & 0.32 & $1.28 \mathrm{~b}$ & 1.34 & 35.98 & 35.18 \\
\hline $\begin{array}{l}{ }^{t} \text { triad } \\
2^{\text {nd }} \text { triad }\end{array}$ & N.S. & s. & N.S. & N.S. & s. & N.S. & N.S. & N.S. \\
\hline
\end{tabular}

Means with different letters within each column are significant at $\mathrm{P}<0.05$ level and means without letters are not significant LSD = least significant difference. $\mathrm{C}=$ Control $\quad \mathrm{T}=$ Treatment $\mathrm{K}=$ Kristalon $\mathrm{H}=$ Honey $\mathrm{V}$. =Versus 


\subsection{Phosphorus percentage (Table 4)}

No clear trend was observed in either season, on comparing different treatments with either of the two controls. Almost the same mean values were also recorded with the honey-Kristalon combination treatments and with the honey-alone treatments. The highest phosphorus percentage in dry leaves was that with $1 \%$ honey alone in the first season, and with $2 \%$ honey + Kristalon in the second.

\subsection{Potassium percentage (Table 4)}

No common Table differences were recorded with different treatments in comparison to either control in either season. The honey-Kristalon triad of treatments had higher mean values in both seasons in comparison to the honey-alone triad, with the difference being significant only in the first season. The highest potassium percentage in dry leaves was that with the $2 \%$ honey + Kristalon treatment in the first season, and with the $1 \%$ honey + Kristalon treatment in the second.

\subsection{Total carbohydrate percentage}

Regarding comparison with $\mathrm{C} 1$, almost all treatments gave higher results in the first season, while only T5 and T6 had higher results in the second. In comparison to $\mathrm{C} 2$, most of the treatments were slightly higher in both seasons. The mean value of carbohydrate percentage was insignificantly higher with the first triad of treatments in the first season 38.43 versus $35.98 \%$ ), and with the second triad in the second season 35.18 versus $33.29 \%$ ). The highest result was recorded with honey at $1 \%$ in both seasons.

In general, the lowest concentration of $1 \%$ honey was in most of the results the more effective one, compared to the higher 1.5 and $2 \%$ concentrations.

Dilute glucose solutions were used by Gharib and Hanafy (2005), for spraying pea plants with resulting increase in leaf area, number of leaves and plant height.

Propolis is another bee product which is a resinous substance collected by honeybees from leaf buds and cracks in the bark of various plants. It is composed of $50 \%$ resin (composed of flavonoids and related phenolic acids), 30\% wax, 10\% essential oils, 5\% pollen and 5\% various organic compounds (Pietta et al, 2002). Propolis extract was used by Rady (2002) to pre-soack seeds/grains of wheat, sugar beet, maize and sorghum, under different soil conditions, with resulting highest germination percentage and improved vegetative parameters.

The overall analyzed results of this study indicate that, regular spraying of diluted honey for Singonium podophyllum plants with, or even without Kristalon was associated with adequate growth of the above ground plant parts, with fluctuation of superiority between the use of honey alone or its use combined with the chemical fertilizer, Kristalon. Being a source of many essential plant nutrients and trace elements, honey can thus represent a highly nutritious fortifying bio-fertilizer, that may be used alone or in conjunction with another fertilizer, with almost the same, or slightly different results. However, the amount of available information is in need of further studies on different plants, using honey with /or alternative to different fertilizers to portrait a more clear picture of this bio-fertilizer in plant life. 


\section{REFERENCES}

A.O.A.C. (1960). Official Methods of Analysis (9 $9^{\text {th }}$ Ed.). Association of Official Analytical Chemists. Washington D.C., USA.

Dewis, J. and F. Freitas (1970): Physical and chemical methods of soil and water analysis. Food and Agric. Organization of the United Nations. Soil Bulletin No. 10.

Doncheva, S.; V. Vassileva; G. Ignatov; S. Pandev; R. Dris and R. Niskanen, (2001): Influence of nitrogen deficiency on photosynthesis and chloroplast ultra structure of pepper plants. Agricultural-and-Food-Science, Finland; 10 (1):59-64.

Dubois, M.; Smith, F.; Gilles, K.A.; Hamilton, J.K. and Rebers, P.A. (1956). Colorimetric method for determination of sugars and related substances. Annal. Chem., 28 (3):350-356.

Gharib, A.A. and A.H. Hanafy (2005): Response of pea plants (Pisum sativum L.) to foliar application of putrescine, glucose, Foliafeed D and silicon. J. Agric. Sci. Mansoura Univ.; 30 (12):7563-7579.

Havsteen, B. H. (2002): The biochemistry and medical significance of the flavonoids. Pharmacology \& Therapeutics, November-December; 96 (2-3):67-202.

Hermosín,I.; R. M. Chicón and M. D. Cabezudo (2003): Free amino acid composition and botanical origin of honey. Food Chemistry, November; 83 (2):263-268.

Kang, J.G. and M.W.V. Iersel (2004): Nutrient solution concentration affects shoot:root ratio, leaf area ratio and growth of subirrigated salvia (Salvia splendens).Hort. Science;39 (1):49-54

Khattab, M.E. (1997): growth and yield response of roselle new cultivars to foliar nutrient application. Bulletin of the Nationa Research Center Cairo, 22 (4):473-494.

Küçük, M.; S. Kolaylı; Ş. Karaoğlu; E. Ulusoy; C. Baltacı and F. Candan(2007): Biological activities and chemical composition of three honeys of different types from Anatolia. Food Chemistry, 100(2):526-534.

Maurizio, A. (1975): How bee makes honey. In: Carne, E.; Honey: A Comprehensive survey, London: Heinemann, pp. 77-105.

Ouchemoukh, S. H. Louaileche and P. Schweitzer (2007): Physicochemical characteristics and pollen spectrum of some Algerian honeys. Food Control, January; 18(1):52-58.

Utriainen, J. and T. Holopainen (2001): Influence of Nitrogen and phosphorus availability and ozone stress on Norway spruce seedlings. Tree physiology; 21(7):447-456.

Pietta P. G.; C. Gardana and A. M. Pietta (2002): Analytical methods for quality control of propolis. Fitoterapia, November; 73, Supplement 1:S7-S20.

Rady, M.M. (2002): Response of propolis extract-presoaking seeds of some crops to salt tolerance under different soil conditions. Ph.D. Thesis, Dep. of Agric. Botany, Faculty of Agric., Fayoum, Cairo Univerity, Egypt. 
Rashed, M. N. and M. E. Soltan (2004): Major and trace elements in different types of Egyptian mono-floral and non-floral bee honeys. Journal of Food Composition and Analysis, December; 17(6):725-735.

Saric, M.; R. Curi and T. Cupina (1976): Chlorophyll Determination. Univ. Unoven Sadu Par Ktikum is fiziologize Piljaka, Beogard, Hauncna, Anjiga, 215

Shin, H. S. and Z. Ustunol (2005): Carbohydrate composition of honey from different floral sources and their influence on growth of selected intestinal bacteria: An in vitro comparison. Food Research International, July; 38(6):721-728.

Snedecor, G. W. and W. G., Cochran (1980): Statistical Methods, $6^{\text {the }}$ ed., Iowa State Univ. Press, Iowa, U S A.

Steel, R. G. D. and J. H. Torrie (1981): Principles and Procedures of Statistics: A Biometrical Approach. $2^{\text {nd }}$ Ed. McGraw-Hill Book Co., New York, NY.

Terrab, A,; A.F. Recamales; D.Hernanz and F.J. Heredia (2004): Characterisation of Spanish thyme honeys by their physicochemical characteristics and mineral contents. Food Chemistry, December; 88(4):537-542.

Troug, E. and A. Meyer (1939): Improvement in deiness colorimetric method for phosphorus and arsenic. Ind. Eng. Chem. Anal. Ed. 1:136-139.

Vázquez, L. C.; M.C. D.Maroto and M.S. Pérez-Coello (2007): Aroma composition and new chemical markers of Spanish citrus honeys. Food Chemistry; 103(2):601-606.

White, J.W. (1975): Physical Characteristics of Honey. In: Carne, E.; Honey: A Comprehensive survey, London: Heinemann, 207-239. 


\title{
دراسة استطلاعية لاستكشاف تأثير عسل النحل كسماد حيوي على النى

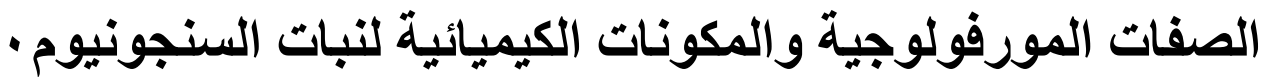

\author{
صفية حمدي محمود الحنفى \\ قسم بساتين الزينة ـ كلية الزر اعة اعلة - جامعة القاهرة- مصر
}

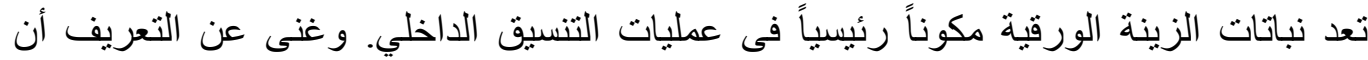

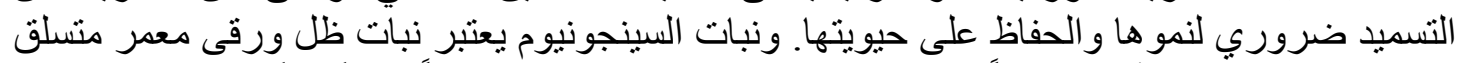

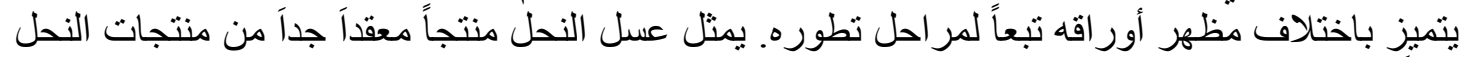
غنياً بالعناصر الرئيسية إضافة إلى النادرة، والتى تعتبر بعضها من مكونات العصبر الخلوي النباتي، إذ إل تمتصه النحلة في صورة رحيق. و تهدف هذه الدراسة إلى استكثناف الآثار الناجمة عن رش تحضير ات الت مخفقة من عسل النحل

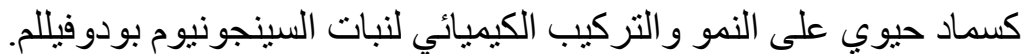

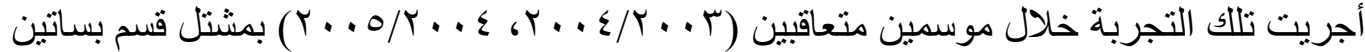
الزينة بكلية الزراعة ، جامعة القاهرة .

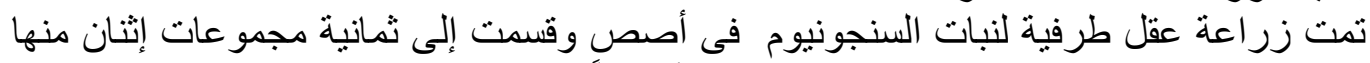

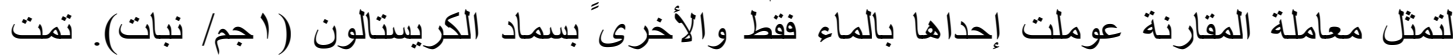

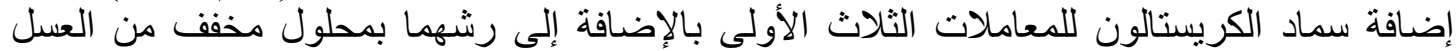

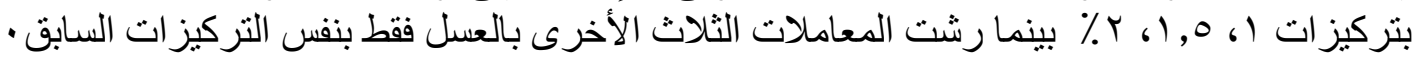

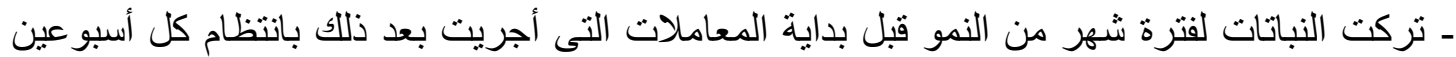

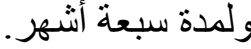

وفى نهاية كل موسم تم تسجيل البيانات المورفولوجية التالية:

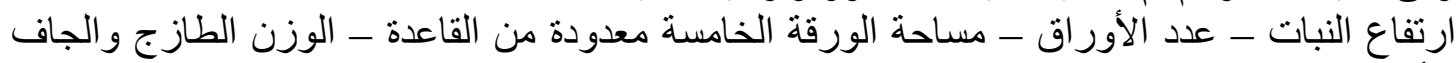

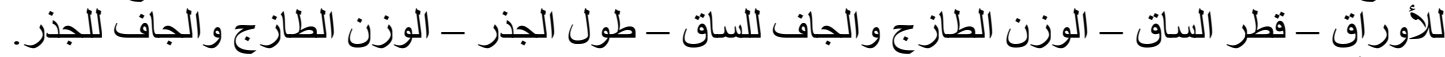
كذللك أجريت التحاليل الكيميائية لتقدير محتوى الأوراق الطازجة من الكائة الصبغات (كلوروفيل أ ، ب و والكاروتينويدات) والنسبة المئوية

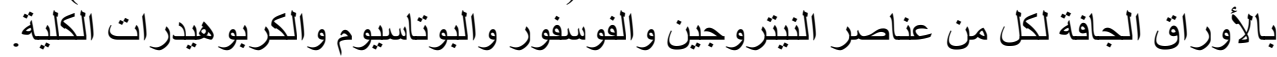

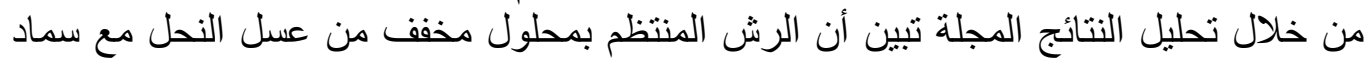

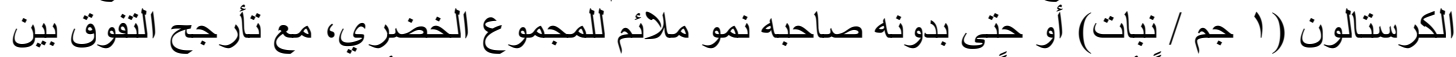

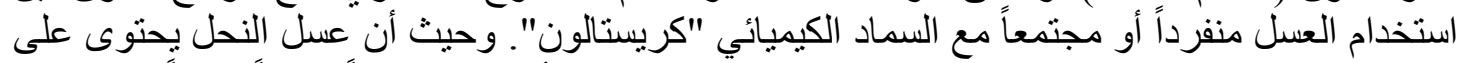

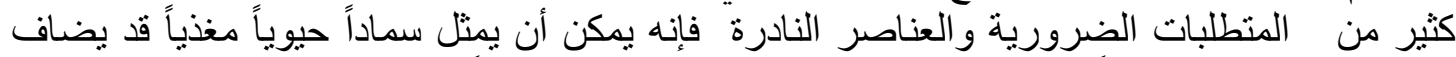

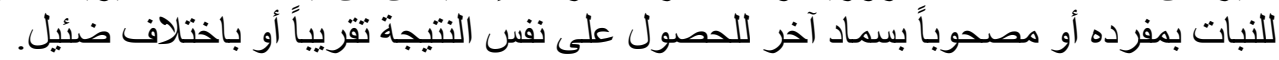

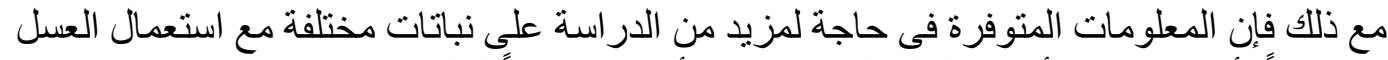

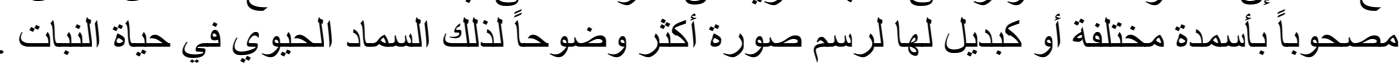

